same period $I$ have ascertained that the cancer mortality in the genesal population among women of the same age was 1 in 15 . Thus the cancer mortality was nearly five and a half times greater for those whose ovaries had been removed than for those who had undergone no such operation. Moreover, the proportion of cancer deaths was much greater among those who had undergone double ovariotomy than in those submitted to the unilateral operation.

The experience of other ovariotomists who have followed up the after-history of their completed cases, as Spencer Wells did (Olshausen, Pfannenstiel, and others) is to the same effect. The gynæcological publications of the last quarter of a century literally teem with confirmatory cases, which might be cited by hundreds. But it would take up too much of your valuable space if I were to proceed further in this direction ; for the present it must suffice if, in concluding this letter, I call attention to only one other indication of this kind-viz., the proclivity to malignant disease manifested by persons with badly developed, rudimentary, or absent ovaries, of which so many examples have lately been reported (Krug, Stroebe, Krabbel, Neugebauer, Unterberger, Audain, Ladinski, Heinricius, Obolonski, Fehling, Hall, and others). In face of such facts as I have instanced, I submit that it is necessary for those who disbelieve in the frequency of malignant disease after removal of the ovaries to support their denial with something more convincing than a pious opinion and a vague appeal to personal experience. am, Sirs, yours faithfully.

Clifton, Bristol, Nov. 21st, 1903.

W. ROGER WILLiaMs.

\section{THE LUNG REFLEX OF ABRAMS.}

\section{To the Editors of THE LANCET.}

SIRS,-Regarding my remarks on the causation of the thoracic expansion which follows upon pulmonary relaxation I must again insist that Dr. A. G. Auld ${ }^{1}$ fails to interpret them correctly. He makes me say in effect that the passive outward recoil of the thoracic walls (ribs, sternum, and diaphragm) " is not alone able to produce a certain degree of thoracic expansion, without, that is, any aid on the part of the muscles of inspiration." In both my previous letters I explicitly state that such recoil is competent to do so. What I, however, contend is that the expansion thus induced will not end here but that the inspiratory muscles will come into extra play so as to tighten up the pulmonary tissues (which would otherwise be unduly relaxed) and maintain pulmonary suction at the normal. I fear that Dr. Auld and I are little likely to agree on this matter, for it is evident that we have fundamentally different conceptions as to the origin, nature, and meaning of pulmonary suction. I have failed to convince him that this phenomenon originates in, and is throughout life maintained and regulated essentially by, the inspiratory muscles. He admits, it is true, that these muscles take part in establishing the suction immediately after birth but contends that thereafter "the conditions are, in fact, reversed and the inspiratory muscles instead of endeavouring to establish a pulmonary suction are in reality directed rather against it." Surely a strange contention. The effect of the inspiratory muscles in breathing is to augment suction: the mean capacity of the chest is greater during breathing than is its capacity at the end of expiration (when we may suppose the inspiratory muscles to cease to act) and therefore suction is in the former case greater than when the chest remains in the expiratory position; from which it is manifest that the inspiratory muscles must throughout life, moment by moment, take a direct and active share in the maintenance of pulmonary suction.

Dr. Auld makes me appear to have laboured under the misapprehension that in stating a mere physiological truismi.e., that pulmonary suction favours cardiac diastole-I was enunciating a new and original view of my own, for, says he, "the function of the pulmonary suction in facilitating cardiac diastole ...... is surely a well-established fact in pneumono-dynamics." May I therefore be permitted to remind him that $I$ did not confine myself to a bald statement of this well-known fact. I contended that the essential function, the raison d'être, of pulmonary suction is to help cardiac diastole, not so much of the ventricles as of the auricles, and notably of the right auricle (which I may here remark is in much more extensive relation with the lung than is the left, as shown by transverse sections of the frozen cadaver), and I further urged that inasmuch as pulmonary suction is essentially dependent upon, and is throughout life vigilantly regulated by, the action of the inspiratory muscles, these latter contribute a constantly active diastolic force, a view which does not, I venture to hope, savour of platitudinism-if I may be allowed the term.

As to the existence of a pulmonary reflex I have, as I said in a former letter, a perfectly open mind, but I am bound to add that much of the evidence advanced by Dr. Auld in its favour seems to me capable of different interpretations from that which he puts upon it. If it is a fact that the fluoroscopic picture shows a local increase of brightness corresponding to the part of the chest wall stimulated we must indeed accept it as strong evidence in favour of the existence of a pulmonary reflex; but when Dr. Auld supports, as he does in his last letter, Dr. Abrams's contention to the effect that the borders of the lung can be made to move more extensively by reflex means than by forcible inspiration, he is accepting as a truth what appears to me to be a physical impossibility. By means of a complete inspiration the borders of the lung are made to travel to the uttermost confines of the pleuræ. How, I would ask, is it possible for them to go further? Assuming, however, that they can by reflex means be made to move thus far, will Dr. Auld still contend that the attendant expansion of the chest can be wholly due to mere passive recoil ?

I am, Sirs, yours faithfully,

Wimpole-street, W., Nov. 22nd, $1903 . \quad$ HARRY CAMPBELl.

\section{THE WALSALL DISTRICT MEDICAL SOCIETY.}

\section{To the Editors of THE LANCET.}

Sirs, - In THE LANCET of Nov. 21st amongst the Birmingham news (p. 1467) reference is made to an article in the Midland Medical Journal on the subject of the secession of the Walsall Medical Society from the Birmingham and District General Medical Practitioners' Union. In that article the Walsall men are attacked rather vigorously and anyone reading it and knowing nothing of the true state of affairs must draw a very uncomplimentary deduction as to the state of things here. As a matter of fact, Walsall has recently been most active in matters of medical reform. The reply to the circular on the subject of touting clubs was that these clubs were almost, if not quite, abolished. The club collector, who formerly went from door to door, gathering pennies and new members for the doctors' clubs, has vanished from the face of the earth. The majority of the medical men in Walsall are holding together to their mutual advantage and Walsall is not by any means in the parlous state that your correspondent thinks, nor in the absolutely deplorable condition suggested by the writer in the Midland Medical Journal.

I am, Sirs, yours faithfully,

FRANK G. LAYTON,

Honorary Secretary, Walsall and District Medical Scciety. Walsall, Nov. 22nd, 1903.

\section{THE PRESENT POSITION OF ETHYL CHLORIDE.}

To the Editors of THE LANCET.

SIRS, - I notice in THE LANCET of Nov. 7th, p. 1305, a review of a little book ${ }^{1}$ which I published just 15 months ago. The review concludes with the remark that ethyl chloride is noticed as a general anæsthetic but "we should judge fails to gain the favour of the writer." Now anyone taking interest in the subject of anæsthetics must be well aware that ethyl chloride has made enormous strides during the past year in this country. It has been very favourably noticed and commented on in nearly every surgical and dental journal in the English language. I myself have contributed a humble quota to the literature of the subject based on a practical experience of some 400 cases and 1 think that in ordinary fairness the gentleman who wrote the review in question might have qualified his remarks-especially in view of the protracted period of gestation-by adding " at the time the book was written."

I may remark that at that time I was using the gas-ether sequence very largely, both in hospital and private work. I never went out to an anæsthetic case unless I had a small

1 A Pocket Guide to Anæsthetics for the Student and General 1 A Pocket Guide to Anæsthetics for the
Practitioner, W. Green and Sons, Edinburgh. 